\section{Identifying and Assessing Na- tional Research Activities on Sustainable Development}

\author{
by Katy Whitelegg, Seibersdorf, Austria
}

The study "Identifying and Assessing National Research Activities on Sustainable Development" was established to provide an overview of national research programmes in the area of sustainable development (SD). The project was part of a process to provide a basis for both Member States and the European Commission to develop joint research activities in the area of SD on the European level. The research programmes of seven European countries were identified and analysed during the study. The analysis included a comparison of the conceptual, thematic and organisational aspects of research programmes in support of SD. The following summary provides an overview of the programmes looked at during the project and outlines the main differences in the organisation of research activities targeted towards SD between the seven countries.

\section{Background to the study}

In the European Union over the past two decades an increasing number of research programmes have been designed that specifically address sustainable development (SD). The main motivation behind such research programmes is the integration of social and economic goals with environmental research. The programmes focus on understanding and developing solutions to the normative goals of SD. These goals place new and different requirements on current research methods and practises including problem-orientated research, the involvement of different actors and the need to integrate a wider range of academic disciplines.

Not only the Member States have been addressing the potential role of research in supporting SD strategies. The European Commission has also organised a series of workshops to address the role of national and EU research activities in supporting transition to SD. They have focused on looking at how research activities can contribute to the six key threats $^{1}$ to SD identified by the European Commission at the Gothenburg Summit (Euro- pean Commission 2001). One part of this process was the $\mathrm{ESTO}^{2}$ project "Identifying and Assessing National Research Activities on Sustainable Development" carried out between September 2001 and June 2002.

\section{Aims and Objectives}

The study aimed to identify and assess research activities in support of SD on the member state level as a first step to defining activities to be taken jointly on the European level. Five project partners ${ }^{3}$ were involved in assessing the research programmes of seven countries; Austria, Belgium, Germany, the Netherlands, Portugal, Sweden and the UK. Although not a comprehensive review, the countries selected cover a wide range of examples of different national contexts for organising research for SD and also of approaches to the design of individual programmes.

The project consisted of three stages. In the first instance, the key actors were mapped who are involved in both designing and implementing the research programmes. In a second stage, the research programmes were identified that support SD and in a final stage the programmes were assessed as to their ability to address the three pillars of SD (environmental, economic and social). To support the assessment phase, a list of criteria were drawn up based on the current literature on research for $\mathrm{SD}^{4}$

Two types of programme were taken into consideration; sectoral and targeted programmes. Sectoral programmes are those programmes that focus on one of the six key threats (see above). Looking at programmes in these areas aims to provide an overview of the kind of national research activities undertaken in each of the EU's priority areas for achieving $\mathrm{SD}$. The targeted programmes were identified through a bottom-up process and includes those national research programmes that specifically target SD. Almost all the countries that were involved in the study have developed programmes that specifically address SD. 


\section{An overview of the programmes identified}

The project looked at a total of 69 research programmes and a further 65 of the Swedish sub-programmes (see Table 1). Included in the 69 research programmes were also a number of funding priorities and measures that are situated on the level below the programme level. These were included as some countries, such as Belgium and Germany, have overarching "umbrella programmes" that consist of a number of highly differentiated sub-programmes. Only considering the programme level would have made an analysis of SD activities difficult. In Sweden, the sub-programmes were also taken into account due to the fact that the programme level is equal to that of a research council and the individual programmes could only be properly be observed on the next level down. research programmes on the national level ${ }^{5}$. Funding for research projects in these countries was mainly channelled through non-specific funding or through other funds not normally associated with research activities such as the EU Structural Fund in Portugal.

\section{Programmes specifically targeted to- wards SD}

Although the project focused both on sectoral and targeted programmes, it looked at the targeted programmes in more detail. These programmes are considerably more innovative in addressing the multiple challenges of SD than the sectoral programmes. They take a systems approach as their starting point and therefore have a broader basis from which to identify the underlying factors of a particular problem. The

Table 1: Overview of National Research Programmes Identified per Country

\begin{tabular}{|l|c|l|}
\hline Country & No. of Programmes & Comments and no. of Sub-programmes \\
\hline Austria & 5 & $\begin{array}{l}\text { National, ministry funded, targeted and sectoral research pro- } \\
\text { grammes }\end{array}$ \\
\hline Belgium & 5 & $\begin{array}{l}3 \text { national SD targeted umbrella programmes which include 13 } \\
\text { thematic and horizontal sub-programmes, 6 regional programmes }\end{array}$ \\
\hline Germany & 6 & $\begin{array}{l}\text { Also described are 3 of the funding priorities and 3 of the fund- } \\
\text { ing measures in the targeted SD programme Research on the } \\
\text { Environment }\end{array}$ \\
\hline The Netherlands & 2 & $\begin{array}{l}\text { Also described are the 5 sub-programmes of the targeted SD } \\
\text { programme Economics, Ecology and Technology Programme }\end{array}$ \\
\hline Portugal & 7 & $\begin{array}{l}\text { Also outlined are the 8 structural fund programmes relevant to } \\
\text { the study, but that are not national research programmes }\end{array}$ \\
\hline Sweden & 35 & $\begin{array}{l}7 \text { funding bodies implementing 65 separate programmes relevant } \\
\text { to the study }\end{array}$ \\
\hline UK & National, ministry and research council funded programmes \\
\hline
\end{tabular}

Source: Whitelegg, K.; Weber, M.; Leone, F., 2002

A considerable proportion of the individual programmes (35) that were looked at are in the UK. Here, the devolved responsibilities for programme design and funding have led to the development of individual and unrelated programmes in comparison to the more structured and co-ordinated approach to programme design in Belgium, Germany and the Netherlands. In Austria and Portugal there are few defined sectoral programmes are more focused and less inclusive in terms of the approaches taken and the actors involved.

The thematic content of the targeted programmes reveals similar patterns across the seven countries. The types of programme can be broadly divided into six categories: 
- Programmes that focus on the structural and behavioural aspects of implementing SD

- Programmes that have a strong thematic focus on a specific system such as sustainable consumption, nutrition, health

- Programmes that have a spatial focus either regional or urban, eco-system based

- Programmes that focus on sustainable technologies and innovation systems (sustainable growth)
- Programmes that focus more broadly on sustainable economic development

- Programmes that address the interaction between global change and SD

Listed in Table 2 are the programmes that were identified during the project as targeting SD. The Table shows the three main programme types for organising research for SD; umbrella programmes, sub-programmes and individual programmes.

Table 2: Overview of Targeted SD Programmes

\begin{tabular}{|c|c|}
\hline Country & Programme \\
\hline $\begin{array}{l}\text { Austria } \\
\text { (individual programmes) }\end{array}$ & $\begin{array}{l}\text { Austrian Landscape Research } \\
\text { Austrian Programme on Technology for Sustainable Development } \\
\text { PFEIL 05 Programme for Research and Development in Agriculture, Forestry, Environ- } \\
\text { ment and Water Management }\end{array}$ \\
\hline $\begin{array}{l}\text { Belgium } \\
\text { (umbrella programmes and } \\
\text { sub-programmes) }\end{array}$ & $\begin{array}{l}\text { Scientific Support Plan for a Sustainable Development Policy } 1 \\
\text { (Sustainable management of the North Sea, Global Change and Sustainable Develop- } \\
\text { ment, Antarctica 4, Sustainable Mobility, Norms for Food Products, Telsat 4, Levers for } \\
\text { a Sustainable Development Policy and Supporting actions) } \\
\text { Scientific Support Plan for a Sustainable Development Policy } 2 \\
\text { (Sustainable Modes of Production and Consumption, Global Change, Eco Systems and } \\
\text { Bio-diversity, Supporting Actions and Mixed Actions) } \\
\text { Scientific Support to an Integration of Notions of Quality and Security of the Production } \\
\text { Environments, Processes and Goods in a Context of Sustainable Development }\end{array}$ \\
\hline $\begin{array}{l}\text { Germany } \\
\text { (umbrella programme and } \\
\text { sub-programmes) }\end{array}$ & $\begin{array}{l}\text { Research on the Environment } \\
\text { (Research on Sustainable Economic Management, Regional Sustainability, Research on } \\
\text { Global Change, Socio-Ecological Research) }\end{array}$ \\
\hline $\begin{array}{l}\text { The Netherlands } \\
\text { (umbrella programme with } \\
\text { structured and co-ordinated } \\
\text { individual programmes) }\end{array}$ & $\begin{array}{l}\text { Economy, Ecology and Technology (EET) } \\
\text { Dutch Initiative for Sustainable Development (NIDO) } \\
\text { HABIFORM (Expertise Network - Multiple Use of Space) }\end{array}$ \\
\hline $\begin{array}{l}\text { Sweden } \\
\text { (individual programmes) }\end{array}$ & $\begin{array}{l}\text { Urban and Regional Planing } \\
\text { Infrasystems for Sustainable Cities } \\
\text { The Sustainable City } \\
\text { Economics for Sustainable Development } \\
\text { Sustainable Forestry in Southern Sweden } \\
\text { Sustainable Food Production } \\
\text { Sustainable Coastal Zone } \\
\text { Sustainable Management of the Mountain Region } \\
\text { Paths to Sustainable Development - Behaviour, Organisations, Structures (Ways Ahead) } \\
\text { Innovation Systems Supporting a Sustainable Growth }\end{array}$ \\
\hline $\begin{array}{l}\mathrm{UK}^{6} \\
\text { (individual programmes) }\end{array}$ & $\begin{array}{l}\text { Environmental Strategy Research Programme } \\
\text { Towards a Sustainable Urban Environment } \\
\text { EPSRC Infrastructure and Environment Programme } \\
\text { Environment Agency Sustainable Development R\&D Programme } \\
\text { Sustainable Development Commission } \\
\text { Sustainable Technologies Initiative - LINK Programme }\end{array}$ \\
\hline
\end{tabular}

Source: Whitelegg, K.; Weber, M; Leone, F., 2002 
Although the project's aim was to identify and analyse the individual programmes that supported SD, it became clear that the national context in which the research activities take place plays an important role. The programmes can not be analysed without taking the national context into consideration. There are a number of key issues that influence the thematic and the organisational structure of programmes targeted towards SD. Firstly, the national research system and especially the research funding system. Secondly, the existence of a national SD strategy and the links between such a strategy and research policy. Thirdly, the existence of a definition of the role research can play in the transition towards SD and finally, methods for overcoming the barriers inherent in national research systems to developing and implementing SD programmes.

\section{National research systems and research for SD}

The organisation of national research systems, including funding structures and the national thematic research priorities, plays a significant role in explaining the diverse structures of the programmes listed in Table 2. The existence of programme funding structures able to implement inter-disciplinary programmes influences whether a country has individual programmes or umbrella programmes. In countries with strong thematically-based research councils, the implementation of inter-disciplinary programmes is less likely. Another aspect found to influence the thematic direction of research for SD are national research priorities and underlying research traditions. One such example is the Dutch focus on the search for technological solutions with its concentration on stakeholder involvement.

\section{The links between SD strategies and research policy for SD}

The relationship between national SD strategies and research policy can also be seen in the organisation of the programmes. The following two examples show two very different ways in which research policy for SD can be used to underpin national SD policy. In two of the countries looked at during the study there was a direct link between the national SD strategy and a research policy for SD. In both Belgium and the Netherlands, research for SD supports the implementation of the national SD strategy. The Belgium "Scientific Support Plan for a Sustainable Development Policy" aims to create a more integrated approach both to policy making and to methods used in designing and implementing research activities. The plan was developed by the Office for Scientific, Technical and Cultural Affairs together with representatives of other ministries. In the Netherlands general policy, SD policy and research policy are all combined within one policy making process. In 1989, the "National Environmental Policy Plan" introduced the idea of supporting research on SD that went beyond traditional research on environmental themes.

\section{National SD research policies}

Both Belgium and the Netherlands also have a clear definition of what research for SD is and what kind of role it can play. In Belgium, research for SD aims to provide scientific support for the "Federal Plan on Sustainable Development". The SD programmes in the Netherlands pursue a slightly different aim. They focus on de-linking economic growth from environmental stress and achieving "trend breaks" in production and consumption patterns. In comparison to the Belgium programme, the Dutch programme focuses on involving the key players in creating and diffusing change.

The German targeted programme also focuses on the inclusion of field actors as one of the key elements of organising research for SD. The programme focuses on the need to change research methods and practises in order to be able to address new topics, to include new actors and to move towards becoming involved in change rather than observing it.

\section{Overcoming barriers to SD research}

Programmes that focus on SD face the challenges of how to integrate different actors and disciplines and to focus on problems of a specific and local nature where the outcome will be context specific knowledge as opposed to general theories. Such requirements pose challenges to the current way in which research processes 
are organised and require new research methods and practises to be developed and established.

During the third stage of the project, which looked at the ability of the programmes to address the three pillars, the means and ways in which the programmes rise to the challenges were assessed. The assessment mainly concentrated on looking at process criteria. The assessment criteria included addressing different time frames, taking the local and the global dimension into account, examining how interdisciplinarity was dealt with and also looking at how the involvement of different stakeholders took place.

The programmes in the three countries described already above, Belgium, Germany and the Netherlands, display the more innovative approaches to overcoming the challenges of designing and implementing SD research activities within current research systems. These countries have, to varying degrees, put into place mechanisms that specifically address inter-disciplinarity and trans-disciplinarity. The approach taken by the Belgium programme is based on developing a programme structure that allows single discipline-based research in the natural sciences to be carried out whilst developing methods for integrating it with social and economic dimensions. The Dutch and the German programmes concentrated, amongst other things, on the inclusion of non-academic stakeholders. As was the case in Belgium, this was not undertaken on a project by project basis, but was a fundamental part of the programme design.

The main conclusions drawn from the project are that research for SD is about finding solutions to national, regional and local problems within their own contexts. This involves using a range of different stakeholders with specific context-based knowledge to explore solutions. Each country, however, faces the same problems and barriers when trying to design and implement programmes that demand considerable changes to current research methods and practises.

The results of the project formed the basis of a two day workshop in Seville in June 2002. The workshop, which was organised by the Institute for Prospective Technological Studies (IPTS), was attended by programme managers from the national SD research programmes and also from the European Commissions research programmes. Over the two days, the discussions revealed the range of different views on the aims and methods of research in support of SD. However, the exchange provided a first step to the development of joint European activities.

\section{Notes}

1) The key threats to SD in Europe identified in Gothenburg are Global warming, Threats to public health, Poverty and social exclusion, Ageing of the population, Loss of bio-diversity and Transport congestion.

2) ESTO is the European Science and Technology Observatory network, a network of research organisations in Europe, set up by the European Commission's JRC-IPTS.

3) The five partners involved in the project were: Sustainable Europe Research Institute (SERI), Austria; Vito - Flemish Institute for Technological Research, Belgium; Technology and Environment Studies, Department of Manufacturing Engineering and Management, Technical University of Denmark, Denmark; Institute for Technology Assessment and Systems Analysis (ITAS), Germany and PREST, University of Manchester, UK. Three further partners were also subcontracted to the project: The Centre for European Economic Research, Germany; Delft University of Technology, the Netherlands and University of Durham, UK.

4) The criteria were based on literature on the Dutch programme (Weaver et al. 2000) and from the recently established UK Sustainable Development Research Network (DEFRA 2000).

5) Although research in Austria is generally funded through non-specific research funds, there are a few programmes on the national level. One of these is the Austrian Landscape Research Programme, a highly regarded targeted programme for more than a decade that had its funding cut in May 2002.

6) Not all UK programmes identified in the country report as addressing SD have been included in this table to be able to compare the programmes across the seven countries.

\section{Literature}

DEFRA - Department for Environment, Food \& Rural Affairs, 2002: Sustainable Development Research: Gaps and Opportunities. http:/www.defra. gov.uk/environment/sustainable/research/gapsopps/ index.htm 
European Commission, 2001: A sustainable Europe for a better world: A European Union Strategy for Sustainable Development. The Commission's proposal to the Gothenburg European Council. Communication from the Commission $\operatorname{COM}(2001) 264$, 15.5.2001

Weaver, P.; Jansen, L.; Van Grootveld, G.; Van Spiegel, E.; Vergragt, P., 2000: Sustainable Technology Development. Sheffield, UK: Greenleaf Publishing

Whitelegg, K.; Weber, M.; Leone, F., 2002: National Research Activities and Sustainable Development. Research Report EUR 20389 EN. Vienna, Sevilla: ARC/JRC-IPTS

Further information on the project, the final report and the individual country reports can be found on the Institute for Prospective Technological Studies (IPTS) web site under: http://www.jrc.es/cfapp/reports/details.cfm?ID $=1017$.

\section{Contact}

Katy Whitelegg

ARC Seibersdorf Research GmbH

Department of Technology Policy

A-2444 Seibersdorf, Austria

Tel.: +43 (0) 505503893

Fax: +43 (0) 505503888

E-Mail: katy.whitelegg@arcs.ac.at

\section{Roadmapping - Eine Methode für den IKT Bereich? Das Projekt ,Nachhaltige Informations- und Kommunikationstechnik (NIK)}

\author{
von Mario Dompke, Kerstin Folk, Kerstin \\ Lahser und Uwe Weigmann, Deutsches \\ Zentrum für Luft- und Raumfahrt e.V., Pro- \\ jektträger im DLR
}

Die Enquetekommission des 13. Deutschen Bundestages „Schutz des Menschen und der Umwelt" hat in Ihrem Bericht „Konzept Nachhaltigkeit" die Notwendigkeit der Integration von Nachhaltigkeitsaspekten in die Entwicklung und Nutzung moderner Informations- und Kommunikationstechnik aufgezeigt. Zur Umsetzung der Empfehlung wurde das Deutsche Zentrum für Luft- und Raumfahrt (DLR) vom Bundesministerium für Bildung und Forschung mit dem Projekt „Nachhaltige Informations- und Kommunikationstechnik" (NIK) beauftragt. Aufgabe von NIK ist es, mittels der Methode des Roadmappings Verknüpfungsmöglichkeiten zwischen den Herausforderungen des nachhaltigen Wirtschaftens mit der Entwicklung zur Informationsgesellschaft aufzuzeigen. Hierzu werden im Dialog zwischen Wirtschaft, Wissenschaft und Politik Innovationspfade für technologische, wirtschaftliche und gesellschaftliche Entwicklungen eruiert und die Methodik anhand der erreichten Ergebnisse und aufgetretener Schwierigkeiten evaluiert. Der vorliegende Artikel stellt neben der Methodik und den Zwischenergebnissen insbesondere die bisherigen Erkenntnisse zur Eignung des Roadmappings für branchenübergreifende Bereiche dar und gibt Hinweise, für welche Themenstellungen mit welchen Zielgruppen sich das Verfahren eignet.

\section{Ausgangslage}

Die Empfehlung der Enquetekommission aufgreifend, hat die Bundesregierung über das Bundesministerium für Bildung und Forschung das Projekt NIK (,Nachhaltige Informationsund Kommunikationstechnik") initiiert und dem Deutschen Zentrum für Luft- und Raumfahrt (DLR) den Auftrag zur Durchführung erteilt. Am Projekt sind neben dem DLR auch die Fraunhofer Gesellschaft (Institut für $\mathrm{Zu}$ verlässigkeit und Mikrointegration/IZM), das 